\title{
Methods of organizing competence-oriented classes with students of pedagogical areas of training
}

\author{
L.G. Shestakova ${ }^{1 *}$, and T.V. Richter ${ }^{2}$ \\ ${ }^{1}$ Perm State University, Perm, Russia \\ ${ }^{2}$ Perm State University, Perm, Russia
}

\begin{abstract}
Object: to describe the methods of organizing competenceoriented classes with students of pedagogical areas of training. Methods: the leading research methods were the generalization and analysis of pedagogical experience and the processing of quantitative data on the dynamics of indicators of the effectiveness of using the methods of organizing competence-oriented classes with students of pedagogical areas of training. Findings: principles of organizing competence-oriented training with students of pedagogical areas of training (systematic, flexibility, interaction, conscious perspective, professional expediency, activity, activity, ideality, humanism, feedback, reflexivity); revealed the advantages of using competence-oriented classes with students of pedagogical areas of training; formulated types of competence-oriented classes with students of pedagogical areas of training; methods of organizing lecture, seminar and practical competence-oriented classes have been developed; identified types of activities (areas of work) for inclusion in the rating indicators; The indicators for assessing the effectiveness of the described methods of work were determined. Conclusions: the article presents a list of competencies, examples of competence-oriented tasks aimed at their formation and planned learning outcomes; The indicators for assessing the effectiveness of the described methods of work were determined. The article materials can be useful for heads of educational structures of various levels, teachers of higher educational institutions, teachers of schools, parents.
\end{abstract}

\section{A problem statement}

Currently, the process of modernization of the higher education system in Russia is associated with the implementation of a competence-based approach, which is focused on the development of personal qualities of individuals who are capable of self-improvement and self-development when performing productive innovation activities. Modern society needs specialists who are able to carry out diverse professional and socio-cultural activities, who are ready to cooperate, creatively develop themselves and self-realize, independently

${ }^{*}$ Corresponding author: ipcs-profped@yandex.ru 
make responsible decisions in situations of choice that have competitive qualities and professional mobility.

All of the above points to the need to form professional competencies of university students, including pedagogical areas of training.

\subsection{The objective of the work}

In modern conditions, higher education continues to search for effective means of forming and tracking general cultural, general professional and professional competencies. Zakharova reveals the role of universal competencies in the formation of the personality of university graduates [1].

Kapichnikova \& Romanova \& Didusenko \& Kapichnikov shows that the introduction of universal competencies opens up opportunities to combine the competency approach with the activity and to combine learning with education [2].

Many studies are devoted to the problems of using the competence approach in the educational process (for example, Samarina [3], Burtseva [4], Panteleeva [5]). They studied and described the pedagogical processes of formation of certain competences in a person. When analyzing research in the field of determining effective ways of forming professional competencies of students of pedagogical areas of training, the following were identified: practice-oriented and student-centered education; training, professionally oriented situations; additional education; industrial and educational practice; trainings, business games.

Samarina [3] identifies an algorithm for constructing a competence-oriented lesson, including the following steps: formulating a goal, selecting content, forms of organization, and teaching methods. By competence-oriented lesson, the author understands the lesson in which conditions are created that contribute to the development of students through the implementation of practical activities.

Burtseva [4] highlighted the requirements for a competence-oriented task (problematic and structured, multi-variant tasks and their solutions, continuity, use of knowledge and skills from the relevant subject area, activity orientation, interdisciplinary). The author refers to the structure of the competence-oriented task incentives, task formulation, sources and verification tools.

Panteleeva [5] examines a set of features of the modernization of education using the competence approach. For example, Kharitonova \& Rikhter \& Shestakova [6] consider the evaluative aspect when conducting competence-oriented classes for students of pedagogical areas of training.

In many educational institutions in the United States, training programs based on the competence approach are implemented. The main task of such programs is to improve their professional knowledge.

The orientation of higher education on the formation of competencies as a set of learning outcomes (knowledge, skills, abilities and experience), involves the creation of pedagogical conditions where the student can manifest himself as an intellectual, actively learning personality who can express his social position and individuality. The problems of competence formation are devoted to the work of many researchers (for example, Aksu \& Koruklu [7], Battilotti [8], Bezusova \& Richter \& Sugrobova \& Chugainova \& Shestakova [9]).

In our opinion, one of the effective tools for the formation of professional competencies of students of pedagogical areas of training is the use of competence-oriented classes in the educational process.

Maslova examines the didactic principles of competence-based learning in the design of a modern lesson [10]. Kislyakova \&Afanasyeva identify the features of the competence- 
based approach in the design of learning technologies [11]. Verem'eva considers training as a competence-oriented technology of teaching at a university [12].Zulpukarova \& Arkalykov reveal the technology of development of competence-oriented mathematical problems [13].

Many aspects of the use of elements of competence-oriented training in mastering the mathematical disciplines are devoted to certain aspects (for example, Chan [14], Dhatsuwan \& Precharattana [15], Jasečková \& Krivoňáková [16], In'am [17], Ramirez-Benavides \& Guerrero [18], Sadi \& Cakıroğlu [19], Seyhan [20]).

Experience in the use of the educational process of competence-based learning has Lehigh University Summer Engineering Institute.

Higher education is faced with the task of forming a set of competencies among students and tracking the results of this process. To accomplish the task, it is necessary to direct each lesson to the formation (and tracking) of competences. In the practice of the university lectures, seminars, practical, laboratory classes are traditionally used.

The research methods were:

1) generalization and analysis of pedagogical experience described in the psychological, pedagogical and methodological literature;

2) processing of quantitative data on the dynamics of indicators of the effectiveness of the use of the methods of organizing competence-oriented classes with students of pedagogical training areas.

\section{Materials and the results of the research}

The principles of the organization of competence-oriented classes with students of pedagogical areas of training are identified:

- systematic (consists in the continuous nature of the use of competence-oriented activities in the formation of professional competencies);

- feedback (the process of systematic monitoring of educational activities);

- flexibility (expressed in the observance of the individual pace of learning, its differentiation);

- interaction (the process of cooperation between the subjects of the educational process);

- humanism (the most favorable conditions for mastering socially accumulated experience, concluded in the content of training, development and manifestation of creative individuality, high civil, moral, intellectual and physical quality);

- a conscious perspective (an individual educational program of study is provided, which contains a plan of action for mastering the complex of professional competences);

- professional expediency (the use of competence-oriented classes in the educational process in accordance with the formed professional competencies);

- activity (the use of intensive mental and practical activities in mastering the complex of professional knowledge and skills);

- activities (the formation of professional competencies through various types of educational activities);

- ideality (possible further interaction and mutual enrichment of the received information resources in the educational process).

The advantages of using competence-oriented classes with students of pedagogical areas of training are revealed:

- the formation of competencies, personal qualities that allow you to operate effectively in various life situations;

- involvement in active independent cognitive activity;

- the use of a variety of activities; 
- the possibility of awareness by students of how to apply knowledge.

The types of competence-oriented classes with students of pedagogical areas of training are formulated:

- classes focused on the use of knowledge in a standard situation with an awareness of how to use knowledge;

- Activities focused on the use of knowledge in an unusual situation with an awareness of how to use knowledge.

Based on the tasks and features of the methodological disciplines in the preparation of student teachers, the following activities (work) for inclusion in the rating indicators were identified.

1. Presentations at seminars with presentations, reports, essays, reviewing speeches (written works) of other students, participation in discussions, discussions, etc.

2. Design, presentation and / or protection of methodological support of in-class and extra-curricular work with schoolchildren (abstracts of lessons, extracurricular activities, comparative analysis of school textbooks, elective course programs, elective courses, educational programs, etc.). The described work is carried out in the framework of classroom studies (practical and laboratory) and for extracurricular students (as a means of verifying the results of independent work of students). Types of work are distributed between the methodological disciplines of the basic and variable parts. Senior students traditionally take part in the annual competition of teaching materials, held at SGPI branch PGNIU.

3. Conducting research work on the material of methodical disciplines. Mandatory for all students are the preparation and protection of the essay on the material of the methodology (second course), preparation and defense of course work (3 course), participation in the scientific and practical conference with the results of final qualifying work (final course).

4. Self-analysis and mutual evaluation of the formation of professional competencies assigned to the discipline (conducted at the beginning and end of the study of the discipline or semester). Students must be included in the assessment activity. At the same time, we orient students to avoid unfounded estimates and judgments. So when evaluating the competence of competences, the task is to identify the types of work and activities that the student demonstrates, to give confirmation.

5. The rating necessarily includes the opportunity to receive additional (not mandatory) points for individual works. The student himself decides whether he will do this work. Here, students can prepare articles, take part in scientific conferences, competitions. This indicator indicates the interest and activity of the student. The results of this work also supplement the student portfolio.

When planning types of work for the rating, it is advisable to proceed from the fact that senior students are given greater freedom. The student has the opportunity to perform tasks in the framework and on the material of the course work, final qualifying work, work experience. For example, a sufficiently wide range of works can be presented for a contest of methodical developments: a synopsis, an elective course program, a training program, a set of visualization, etc.

Defined indicators for assessing the effectiveness of the described methods of work:

1. The share of students participating in scientific and methodological competitions held on the basis of the university and outside the university.

2. The proportion of students participating in scientific conferences.

3. The share of graduate students who have publications.

4. The number of diplomas and certificates received by students.

5. The share of students performing additional (optional) individual tasks in methodical disciplines. 
In Table 1 presents a list of competencies, examples of competence-oriented tasks aimed at their formation and planned learning outcomes.

Table 1. The list of competencies, examples of competence-oriented tasks aimed at their formation and the planned learning outcomes.

\begin{tabular}{|c|c|c|}
\hline Shaped competence & $\begin{array}{l}\text { Competence-oriented } \\
\text { task }\end{array}$ & Planned learning outcomes \\
\hline $\begin{array}{l}\text { To realize the social } \\
\text { significance of their future } \\
\text { profession, to have the } \\
\text { motivation to carry out } \\
\text { professional activities. }\end{array}$ & $\begin{array}{l}\text { Preparation and protection } \\
\text { of the abstract on the } \\
\text { method of teaching } \\
\text { mathematics. }\end{array}$ & $\begin{array}{l}\text { Demonstrates competence on the } \\
\text { subject matter. Gives own assessment, } \\
\text { offers a solution. Competently builds a } \\
\text { speech, the answers to questions. } \\
\text { Actively participates in the discussion, } \\
\text { asks questions. }\end{array}$ \\
\hline $\begin{array}{l}\text { Willingness to implement } \\
\text { educational programs in the } \\
\text { school subject in } \\
\text { accordance with the } \\
\text { requirements of educational } \\
\text { standards. }\end{array}$ & $\begin{array}{l}\text { The choice of techniques, } \\
\text { forms methods and } \\
\text { means of teaching } \\
\text { mathematics in a } \\
\text { particular class. }\end{array}$ & $\begin{array}{l}\text { Know the content and principles of the } \\
\text { construction of school programs and } \\
\text { textbooks in mathematics; methods, } \\
\text { techniques and forms of organization of } \\
\text { the educational process in mathematics; } \\
\text { means of education; methods of } \\
\text { teaching school mathematics. To be } \\
\text { able to systematically analyze and } \\
\text { choose educational concepts, } \\
\text { technologies, techniques, forms, } \\
\text { methods and means based on the goals } \\
\text { and objectives of the training; take into } \\
\text { account in the pedagogical interaction } \\
\text { (in teaching mathematics) the various } \\
\text { features of students; carry out the } \\
\text { process of learning mathematics in } \\
\text { various age groups and various types of } \\
\text { educational organizations. To possess } \\
\text { various means of communication in } \\
\text { professional pedagogical activity. }\end{array}$ \\
\hline $\begin{array}{lll}\text { Ability to develop } & \text { and } \\
\text { implement cultural } & \text { and } \\
\text { educational programs. } & \end{array}$ & $\begin{array}{l}\text { Develop an outline of } \\
\text { extracurricular activities } \\
\text { in mathematics. }\end{array}$ & $\begin{array}{l}\text { To know the essence of the cultural and } \\
\text { educational program. To be able to } \\
\text { organize extracurricular activities and } \\
\text { extracurricular work in mathematics; } \\
\text { develop cultural and educational } \\
\text { programs. Master the techniques of } \\
\text { speaking and writing; ways to interact } \\
\text { with other subjects of the educational } \\
\text { process. }\end{array}$ \\
\hline $\begin{array}{l}\text { The ability to use the } \\
\text { capabilities of the } \\
\text { educational environment to } \\
\text { achieve personal, } \\
\text { metasubject and subject } \\
\text { learning outcomes and to } \\
\text { ensure the quality of the } \\
\text { educational process by } \\
\text { means of the taught } \\
\text { academic subject. }\end{array}$ & $\begin{array}{l}\text { The formulation of the } \\
\text { goals of teaching } \\
\text { mathematics (by the job). }\end{array}$ & $\begin{array}{l}\text { To know the structure and content of } \\
\text { regulatory documents governing the } \\
\text { educational process at school; the } \\
\text { content of the school course of } \\
\text { mathematics and the subject } \\
\text { «Mathematics». To be able to formulate } \\
\text { the goals of learning math. Master the } \\
\text { methods and techniques for } \\
\text { constructing an educational process in } \\
\text { accordance with regulatory documents; } \\
\text { methods of information retrieval, its } \\
\text { processing and presentation. }\end{array}$ \\
\hline
\end{tabular}




\begin{tabular}{|c|c|c|}
\hline Shaped competence & $\begin{array}{l}\text { Competence-oriented } \\
\text { task }\end{array}$ & Planned learning outcomes \\
\hline $\begin{array}{l}\text { Ability to use modern } \\
\text { methods and technologies } \\
\text { of training and diagnostics. }\end{array}$ & $\begin{array}{l}\text { Development of the } \\
\text { calendar plan, the lesson } \\
\text { of math. }\end{array}$ & $\begin{array}{l}\text { Know the modern methods and } \\
\text { technologies of training and } \\
\text { diagnostics. To be able to select and } \\
\text { combine them based on specific } \\
\text { conditions, objectives of the lesson. } \\
\text { Master the techniques of designing a } \\
\text { calendar plan and lesson outline. }\end{array}$ \\
\hline $\begin{array}{l}\text { Ability to design } \\
\text { educational programs }\end{array}$ & $\begin{array}{l}\text { Designing an educational } \\
\text { program in mathematics }\end{array}$ & $\begin{array}{l}\text { Know the requirements for programs. } \\
\text { To be able to determine the educational } \\
\text { objectives of the material being studied } \\
\text { in mathematics; to design an } \\
\text { educational process (based on } \\
\text { mathematics) using modern } \\
\text { technologies that meet the general and } \\
\text { specific laws and peculiarities of the } \\
\text { age development of a person; develop } \\
\text { different models of lessons. Have the } \\
\text { skills to create and edit professional, } \\
\text { educational texts; ways of project } \\
\text { activities in education. }\end{array}$ \\
\hline $\begin{array}{l}\text { Ability to design students' } \\
\text { individual } \\
\text { routes. }\end{array}$ & $\begin{array}{l}\text { Development of elective } \\
\text { elective course in } \\
\text { mathematics. }\end{array}$ & $\begin{array}{l}\text { Know the features of teaching } \\
\text { mathematics in different age groups of } \\
\text { students at different levels of schooling } \\
\text { and in different types of educational } \\
\text { organizations; essence and methods of } \\
\text { level and profile differentiation. To be } \\
\text { able to design elective and elective } \\
\text { courses in mathematics using the latest } \\
\text { achievements of science; use means and } \\
\text { methods of differentiation. To own - } \\
\text { methods of project and innovation } \\
\text { activities in education. }\end{array}$ \\
\hline $\begin{array}{l}\text { Ability to design } \\
\text { trajectories } \\
\text { professional growth } \\
\text { personal development. }\end{array}$ & Analyze the math lesson. & $\begin{array}{l}\text { To be able to analyze the results of } \\
\text { educational activities in order to } \\
\text { improve and improve their skills; } \\
\text { analyze the various models of lessons. } \\
\text { Master the basic methods of } \\
\text { comparison, } \\
\text { systematization; analysis and synthesis; } \\
\text { generalization and specification; ways } \\
\text { of orientation in professional sources of } \\
\text { information (magazines, websites, } \\
\text { educational portals, etc.); ways to } \\
\text { improve professional knowledge and } \\
\text { skills by using the capabilities of the } \\
\text { information environment of the } \\
\text { educational organization, region, } \\
\text { region, country. }\end{array}$ \\
\hline $\begin{array}{l}\text { Willingness to participate } \\
\text { in research. }\end{array}$ & $\begin{array}{l}\text { Preparation and protection } \\
\text { of research work on the } \\
\text { method of teaching }\end{array}$ & $\begin{array}{l}\text { Know the basic requirements for } \\
\text { scientific research. To be able to define } \\
\text { a goal and make a plan for scientific }\end{array}$ \\
\hline
\end{tabular}




\begin{tabular}{|c|c|c|}
\hline Shaped competence & $\begin{array}{l}\text { Competence-oriented } \\
\text { task }\end{array}$ & Planned learning outcomes \\
\hline & mathematics. & $\begin{array}{l}\text { work conduct a selection of literature } \\
\text { based on the purpose and plan of } \\
\text { scientific work; arrange a scientific } \\
\text { work. Master the techniques of } \\
\text { conducting and processing the results of } \\
\text { scientific work; methods of protection } \\
\text { of scientific work. }\end{array}$ \\
\hline $\begin{array}{l}\text { The ability to lead the } \\
\text { educational and research } \\
\text { activities of students. }\end{array}$ & $\begin{array}{l}\text { Organization of research } \\
\text { work on the material of } \\
\text { mathematics. }\end{array}$ & $\begin{array}{l}\text { Know the techniques and forms of } \\
\text { educational research activities of } \\
\text { students. To be able to plan educational } \\
\text { and research activities of students; } \\
\text { organize training and research activities } \\
\text { of students. To master the methods of } \\
\text { integrating teaching and research } \\
\text { activities in the educational process. }\end{array}$ \\
\hline $\begin{array}{l}\text { Ability to self-organization } \\
\text { and self-education. }\end{array}$ & $\begin{array}{l}\text { Preparation of a scientific } \\
\text { report on the method of } \\
\text { teaching mathematics and } \\
\text { speaking at a competition } \\
\text { of scientific reports. } \\
\text { Workshop on the work of } \\
\text { sources in a foreign } \\
\text { language. }\end{array}$ & $\begin{array}{l}\text { To be able to set a goal of self- } \\
\text { education, plan your activities. Master } \\
\text { the techniques of planning and } \\
\text { introspection. }\end{array}$ \\
\hline $\begin{array}{l}\text { The ability to organize the } \\
\text { cooperation of students, to } \\
\text { maintain activity and } \\
\text { initiative, the independence } \\
\text { of students, to develop their } \\
\text { creative abilities. }\end{array}$ & $\begin{array}{l}\text { Development of the } \\
\text { project in mathematics. }\end{array}$ & $\begin{array}{l}\text { Know the techniques of organizing } \\
\text { students' interaction, activation, } \\
\text { development oreativity, } \\
\text { independence on the material of } \\
\text { mathematics. To be able to select } \\
\text { methods of organizing students' } \\
\text { interaction, activation, development of } \\
\text { creativity, independence depending on } \\
\text { the goal. To master the methods of } \\
\text { planning and } \\
\text { extracurricular work. }\end{array}$ \\
\hline
\end{tabular}

In the experimental work carried out on the basis of SGPI branch PGNIU in 2018-2019, students enrolled in undergraduate programs. Pedagogical education (focus (profile): Mathematics, Mathematics and Economics). The total number of students is 45 people. Quantitative results are presented in Table 2.

Table 2. Dynamics of indicators of efficiency of using techniques of competenceoriented classes.

\begin{tabular}{|l|l|l|}
\hline Indicator & $\begin{array}{l}\mathbf{2 0 1 8} \\
\text { year }\end{array}$ & $\mathbf{2 0 1 9}$ year \\
\hline $\begin{array}{l}\text { Percentage of students participating in scientific and methodical } \\
\text { competitions held on the basis of SGPI branch PGNIU }\end{array}$ & $35,7 \%$ & $64,3 \%$ \\
\hline $\begin{array}{l}\text { Percentage of students participating in scientific and methodical } \\
\text { contests held outside the university SGPI branch PGNIU }\end{array}$ & $14,3 \%$ & $25 \%$ \\
\hline Percentage of students participating in scientific conferences & $42,9 \%$ & $71,4 \%$ \\
\hline Share of graduate students with publications & $72 \%$ & $100 \%$ \\
\hline Number of diplomas and certificates received by students & 10 & 18 \\
\hline $\begin{array}{l}\text { Percentage of students performing additional (optional) } \\
\text { individual tasks in methodical disciplines }\end{array}$ & $10,7 \%$ & $42,8 \%$ \\
\hline
\end{tabular}


A methodology for conducting competence-oriented classes for students of pedagogical areas of training has been developed.

In lectures in this regard, the techniques of developing critical thinking will work well. With the help of the reception ZHU (I know - I want to know - I learned) on the basis of the analysis of the stated topic, students at the beginning of the couple write down (and then voice) the answers to the questions. What do i know What I would like to know, what I want to learn, what is interesting? At the end of the pair (or at the end of the stage) we answer the question: what did you learn, what did you learn? What remains to learn or do? From the answers to the last questions, either the goal is set at the next stage of the lecture, or the homework. To maintain the activity and interest of students, the lecturer can use the techniques of problem presentation and partial search method.

Seminars are arranged in such a way that students-speakers do not just present the material, but also master the use of the above-mentioned techniques. In addition to the traditional additions to the answer and the «speaker» questions, you can use the two-part diary technique (the technique can be used when listening to a report, speech, lecture, or when studying some material on your own, for example, from a textbook or original source). A student, in the course of a report or reading a text, writes out a part of it, a sounded thought that impressed him. Next gives a comment.

At a practical lesson (in addition to the above), you can use the techniques «Brainstorming», «Basket of ideas». The stages for these techniques may be the following: thinking about the task at hand (individual work for 3-5 minutes); discussion in pairs or groups (3-5 minutes); voicing of ideas (each group names one of its ideas, not repeating the previously voiced one); analysis of ideas, correction of errors. Reception works well when looking for a solution to a difficult problem, solving a problem. Obviously, these stages can be reduced. For methodical disciplines it is advisable to use business and role-playing games. Students do not just tell how to organize, for example, a lesson, but lose it in a group (which assumes the role of students).

For understanding, generalization and systematization of the material studied, you can use the preparation of analytical schemes, multidimensional schemes, clusters. The reception works well for both the material listened to and recorded at the lecture (as a homework, students are asked to draw up a diagram or cluster as a lecture) and for those studied independently. It will contribute to the comprehension and memorization of material, both lectures and independently studied preparation of a certain set of questions at home. Groups of questions clearly pronounced. These can be: simple questions, clarifying, questions-interpretations, practical, creative and evaluative questions, etc. For the purpose of developing students' motivation and creative abilities, you can use the end of the lesson, the themes of synquain composing (in French means a five-line poem).

Planning competency classes is not possible without the inclusion of a control phase aimed at tracking the formation of the elements that make up the competencies. In the classroom (both classroom and extracurricular) you need to increase the activity and motivation of students. A good means of enhancing and motivating is the competent use of a rating assessment of learning outcomes.

The study set the following tasks: to reveal the principles of organizing competenceoriented classes with students of the pedagogical areas of training; identify the benefits of using competence-oriented classes with students of pedagogical areas of training; to formulate the types of competence-oriented classes with students of pedagogical areas of training; identify the types of activities (work) for inclusion in the rating indicators; determine the indicators for evaluating the effectiveness of the described methods of work.

\section{Conclusions}

As a result of the work done: 
- The principles of organizing competence-oriented training with students of pedagogical areas of training are identified: systematic, flexible, interaction, conscious perspective, professional expediency, activity, activity, ideality, humanism, feedback, reflexivity;

- the advantages of using competence-oriented classes with students of pedagogical areas of training: the formation of competencies, personal qualities that allow you to act effectively in various life situations; involvement in active independent cognitive activity; the use of a variety of activities; possibility of understanding by students of how to apply knowledge;

- formulated the types of competence-oriented classes with students of pedagogical areas of training: classes, application-oriented knowledge in a standard situation with an awareness of how to use knowledge; classes focused on the application of knowledge in a non-standard situation with an awareness of how to apply knowledge;

- the following activities (work) were identified for inclusion in rating indicators: presentations at seminars with reports, reports, essays, reviewing presentations (written works) of other students, participation in discussions, debates; designing, presenting and / or defending methodological support for homework and extracurricular work with schoolchildren (abstracts of lessons, extracurricular activities, comparative analysis of school textbooks, elective courses, elective courses, educational programs, etc.); conducting research work on the material of methodical disciplines; self-analysis and mutual evaluation of the development of professional competencies assigned to the discipline;

- indicators for assessing the effectiveness of the described methods of work were determined: the proportion of students participating in scientific and methodological competitions held on the basis of the university and outside the university; the proportion of students participating in scientific conferences; share of graduate students who have publications; the number of diplomas and certificates received by students; the proportion of students performing additional (optional) individual tasks in methodical disciplines.

The described techniques and types of work are implemented in the State Pedagogical Institute of the Perm State Scientific Research Institute at classes on the method of teaching mathematics and methodical courses of choice.

Over the course of 2 years, students gradually master the activities that are part of their professional competencies. As a result, by the end of the bachelor's program, all students have publications on how to learn mathematics, diplomas and certificates of participants in various competitions and conferences.

The use of the described techniques increases activity, the number of students performing additional (optional) individual works of a scientific and methodological nature increases.

\section{References}

1. V.V. Zakharova, Bulletin of the MIIT Law Institute, 2(18), 55-62 (2017)

2. O.B. Kapichnikova, O.V. Romanova, E.N. Didusenko, A.I. Kapichnikov, Higher education today, 5, 21-24 (2019)

3. V.Ya. Samarina, Actual problems of modern general and vocational education: a collection of articles based on the materials of the II All-Russian Correspondence Scientific and Practical Conference, 47-50 (2016)

4. L.P. Burtseva, Knowledge, 11-3 (40), 66-69 (2016)

5. M.V. Panteleeva, Bulletin of SUSU. Series «Education. Pedagogical sciences», 8 (4), 100-104 (2016) 
6. L.G. Shestakova, T.V. Rikhter, E.A. Kharitonova, Indian Journal of Science and Technology, 9 (21), 95221 (2016)

7. G. Aksu, N. Koruklu, Egitim Arastirmalari - Eurasian Journal of Educational Research, 59, 181-206 (2015)

8. G. Battilotti, International Journal of Cognitive Informatics and Natural Intelligence, 8 (4), 83-97 (2015)

9. T.A. Bezusova, T.V. Richter, N.Y. Sugrobova, L.V. Chugainova, L.G. Shestakova, Eurasia Journal of Mathematics, Science and Technology Education, 13(11), 7257-7267 (2017)

10. S.V. Maslova, Humanities and education, 1 (29), 39-42 (2017)

11. O.P. Kislyakova, I.F. Afanasyeva, European Social Science Journal, 10, 402-405 (2018)

12. N.V. Verem'eva, Axiological problems of pedagogy, 10, 35-42 (2019)

13. D.I. Zulpukarova, E.M. Arkalykova, Bulletin of Jalal-Abad State University, 2 (41), 96102 (2019)

14.P.S. Chan, 12th International Conference of the Learning Sciences: Transforming Learning, Empowering Learners, ICLS 2016; National Institute of Education (NIE), Nanyang Technological UniversitySingapore; Singapore, 2, 1302-130 (2016)

15. A. Dhatsuwan, M. Precharattana, Simulation and Gaming, 47 (4), 445-464 (2016)

16. G. Jasečková, N. Krivoňáková, 15th Conference on Applied Mathematics, 614-620 (2016)

17. A. In'am, Global Journal of Pure and Applied Mathematics, 12 (1), 1069-1075 (2016)

18. K. Ramirez-Benavides, L.A. Guerrero, Revista Iberoamericana de Tecnologias del Aprendizaje, 10 (3), 152-159 (2015)

19. Ö. Sadi, J. Çakıroğlu, Croatian Journal of Education, 17 (3), 97-115 (2015)

20. H.G. Seyhan, Asia-Pacific Forum on Science Learning and Teaching, 16 (2), 8 (2015) 